\title{
Prevention of Postnatal Bone Demineralization in Very Low-Birth-Weight Infants by Individually Monitored Supplementation with Calcium and Phosphorus
}

\author{
FRANK POHLANDT \\ Division of Neonatology and Pediatric Critical Care Medicine, Children's Hospital, University of Ulm, \\ Ulm. Germany
}

\begin{abstract}
Preterm infants are more prone to bone mineral deficiency the lower their birth weight. To achieve the intrauterine bone mineral accretion rate postnatally, 74 low-birth-weight infants (median birth weight, $980 \mathrm{~g}$; range 430-1.580 g) were each supplemented enterally and/or parenterally with calcium and/or phosphorus in gradually increased amounts. The aim was to yield a simultaneous urinary excretion of $\mathrm{Ca}$ and inorganic phosphorus $(\mathrm{Pi})$ at low concentrations $(1-2 \mathrm{mmol} / \mathrm{L})$ in spot urine specimens taken twice weekly. The hypothesis was that the intrauterine mineralization rate $\left(4.5 \mathrm{mg} \mathrm{cm}^{-1} / 100 \mathrm{~g}\right.$ weight gain) would be achieved postnatally in very low-birth-weight infants, if they were supplemented with enough $\mathrm{Ca}$ and/or Pi to effect at least a low (1-2 mmol/L) simultaneous urinary excretion of both ions, as compared with infants who do not excrete both ions and would accrete the bone minerals at a lower rate. The change in bone mineral content was measured by single photonabsorption densitometry and related to weight gain during periods of 2 to 6 wk. Infants who simultaneously excreted $\mathrm{Ca}(>1.2 \mathrm{mmol} /$ L) $+\mathrm{Pi}(>0.4 \mathrm{mmol} / \mathrm{L})$ in more than half of the urine samples retrospectively showed the highest bone mineral accretion, $5.1 \mathrm{mg} \mathrm{cm}^{-1} / 100 \mathrm{~g}$ weight gain, which was equivalent to the fetal mineralization rate $(4.5)$. In this group the bone mineral status significantly contributed to the variance of the bone mineral accretion rate; severely demineralized infants showed a catch-up mineralization. A significantly lower rate (2.4) was observed in infants who excreted $\mathrm{Ca}+\mathrm{Pi}$ in less than half of the urinary samples. Supplementation with $\mathrm{Ca}$ and $\mathrm{Pi}$ up to the point where both ions are simultaneously excreted with the urine at concentrations $>1.2$ and $>0.4 \mathrm{mmol} / \mathrm{L}$, respectively, offers a simple and safe way of achieving the fetal bone mineral accretion rate in preterm infants, taking into account their individual needs, the varying mineral content of breast milk, and the different compositions of special-care formulas. A further prospective study is needed to test the hypothesis. (Pediatr Res 35: 125-129, 1994)
\end{abstract}

\section{Abbreviations}

Received August 1, 1991; accepted August 31, 1993

Correspondence: Frank Pohlandt, M.D., Ph.D., Universitäts-Kinderklinik, D 89070 Ulm, Germany.

Supported by Grant Po 187/2-1 from the Deutsche Forschungsgemeinschaft. Presented in part at the 13. Symposium für Neonatologie und Pädiatrische Intensivmedizin April 3-4, 1988, Basel, Switzerland (Pohlandt F 1988 Vermeidung der Skelettdemineralisierung bei sehr kleinen Frühgeborenen. Individuelle Steuerung der Kalzium- und Phosphatsubstitution anhand der Kalzium-, Phosphorkonzentration im Urin. In: Nars PW (ed) Pädiatrische Intensivmedizin IX, Georg Thieme Verlag, Stuttgart, A100-102).
BMA, bone mineral accretion BMC, bone mineral content Pi, inorganic phosphorus VLBW, very low-birth-weight

Postnatal bone mineral deficiency is a condition that is well known (1-6) in preterm infants and that has gained in importance clinically since the rate of survival of VLBW infants has so greatly improved. Various factors were held to be responsible for bone mineral deficiency, such as deficiencies of vitamin $\mathrm{D}$ $(7,8), \mathrm{Ca}(7,9), \mathrm{Pi}(10-13), \mathrm{Ca}+\mathrm{Pi}(14,15)$, as well as parenteral nutrition (16-20), metabolic disease, physiotherapy, long-term ventilation and, finally, treatment with furosemide.

Schilling and co-workers (21) described the pivotal biochemical changes in breast milk- and formula-fed preterm infants and we have confirmed the findings many times (22): feeding with breast milk resulted in the phosphopenic type of rickets with severe hypophosphatemia and an absence of urinary $\mathrm{Pi}$, together with hypercalciuria. In contrast, formula-fed infants were characterized by marginal hypocalcemia, no detectable urinary $\mathrm{Ca}$, and showed secondary hyperparathyroidism together with hyperphosphaturia, i.e. the calcipenic type of rickets. The absence of $\mathrm{Pi}$ or $\mathrm{Ca}$, respectively, from the urine, is explained by maximal tubular reabsorption of these ions, indicating a deficiency of $\mathrm{Ca}$ and $\mathrm{Pi}$, respectively. The inorganic bone material is the crystalline mineral apatite, with the formula $\mathrm{Ca}_{5}(\mathrm{PO} 4)_{3}(\mathrm{OH}, \mathrm{F})(23)$. Owing to the different amounts and ratios of $\mathrm{Ca}$ and $\mathrm{Pi}$ in breast milk and special-care formulas for preterm infants, the limiting factor for bone mineralization was $\mathrm{Pi}$ in breast milk-fed and $\mathrm{Ca}$ in formula-fed infants. The corresponding ion in apatite was surplus and, therefore, excreted with the urine. The hypercalciuria observed in VLBW infants fed breast milk is a paradox because only one-third of the infant's requirement of $\mathrm{Ca}$ is administered by breast milk. The hypercalciuria indicates that the deficiency of phosphorus is even greater than that of calcium and that only a part of the small amount of $\mathrm{Ca}$ can be accreted as apatite. A supplementation with phosphate reduces calciuria to nearly zero and then calcium is the limiting factor. Therefore, VLBW infants fed breast milk need a supplementation with both $\mathrm{Pi}+\mathrm{Ca}$.

The calcipenic type of postnatal bone demineralization develops in VLBW infants fed a special-care formula enriched with $\mathrm{Ca}+\mathrm{Pi}$, because of the low net absorption of $\mathrm{Ca}$.

The hypothesis that we arrived at was that the intrauterine mineralization rate $\left(4.5 \mathrm{mg} \mathrm{cm}^{-1} / 100 \mathrm{~g}\right.$ weight gain) (24) would be achieved postnatally in VLBW infants, if they were supplemented with enough $\mathrm{Ca}$ and/or Pi to effect at least a low (1-2 $\mathrm{mmol} / \mathrm{L}$ ), simultaneous urinary excretion of both ions, as com- 
pared with infants who do not excrete both ions and would accrete the bone minerals at a lower rate. To test this hypothesis we undertook prospectively the study reported here.

\section{MATERIALS AND METHODS}

Supplementation procedure. For enteral supplementation, solid Ca gluconate (food quality, Merck, Darmstadt, Germany) and $\mathrm{Ca}$ glycerophosphate (food quality, Merck) were used and Ca gluconate $20 \%$ (Sandoz, Nürnberg, Germany) and $\mathrm{Na}_{2}$ glucose-1-phosphate (1 mmol/mL, Leopold, Graz, Austria) were used for intravenous administration. The amounts of enteral and/or parenteral $\mathrm{Ca}$ and/or $\mathrm{Pi}$ were at first $2 \mathrm{mmol} / \mathrm{kg}$ a day and then increased weekly $(0.5-1 \mathrm{mmol} / \mathrm{kg}$ a day) until morning spot urinary specimens, which were taken twice weekly, contained both $\mathrm{Ca}+\mathrm{Pi}$ concentrations between 1 and $2 \mathrm{mmol} / \mathrm{L}$. During the study, the doses were adjusted to reach this goal.

We deliberately did not choose a randomized placebo controlled trial but supplemented all VLBW infants in order to study our concept of individually adjusted supplements. This design would provide us with one group of infants who excrete $\mathrm{Ca}+\mathrm{Pi}$ together with urine and a second group who would not. A better mineral accretion rate of the infants excreting $\mathrm{Ca}+\mathrm{Pi}$ would support and equal mineralization in both groups would falsify our hypothesis.

$\mathrm{Ca}$ and $\mathrm{Pi}$ were measured by standard methods during the daily routine $(25,26)$. The lower limits of the method for detecting $\mathrm{Ca}$ was 1.2 and $0.4 \mathrm{mmol} / \mathrm{L}$, respectively, for $\mathrm{Pi}$. The coefficient of variation was $2.3 \%$ for $\mathrm{Ca}$ and $4 \%$ for $\mathrm{Pi}$. The study was approved by the Committee on Human Experimentation of the University of Ulm.

Photon absorption densitometry. BMC was measured in the middle of the right humerus at 3 (range, 2-6)-wk intervals by single photon absorption densitometry as described previously (24). The coefficient of variation was $3 \%$. BMC is best correlated with body weight (24). The change in $\mathrm{BMC}$, therefore, was related to the change in body weight $(\mathrm{mg} \mathrm{cm}-1 / 100 \mathrm{~g}$ ) over the same period.

Patients. All VLBW infants admitted to our unit were eligible for the study. Infants were excluded when they died or were transferred to other hospitals during the first $28 \mathrm{~d}$. Seventy-four VLBW infants (birth weight, median $970 \mathrm{~g}$, range 430-1.580; gestational age, median $28 \mathrm{wk}$, range 24-33) were supplemented with $\mathrm{Ca}$ and/or $\mathrm{Pi}$ (as planned) and observed for a total of 104 periods (median $=2$ periods, range $1-5$ ) of $3 \mathrm{wk}$ (range 2-6). The wide range of observational periods resulted from the variation in birth weight and duration of stay in hospital. The bone mineral accretion rates during these intervals $\left(\mathrm{mg} \mathrm{cm} \mathrm{cm}^{-1} / 100 \mathrm{~g}\right.$ weight gain) were grouped according to the type of $\mathrm{Ca} / \mathrm{Pi}$ urinary excretion observed during these periods: group 1, periods when more than half of the urinary specimens contained both $\mathrm{Ca}(>1.2$ $\mathrm{mmol} / \mathrm{L})$ and $\mathrm{Pi}(>0.4 \mathrm{mmol} / \mathrm{L})$; group 2 , periods when fewer than half of the urinary specimens contained both $\mathrm{Ca}+\mathrm{Pi}$. When data from more than one period was available in one infant, one period was randomly selected for data analysis and statistical comparison. Data were only selected from periods when the parenterally supplied amount of $\mathrm{Ca} / \mathrm{Pi}$ contributed less than $10 \%$ of the total administered dose.

The infants were fed with their own mother's milk when available, this being individually substituted with Alfare (3-6 g/ $\mathrm{dL}$, Nestlé. Munich, Germany) to provide enough energy and protein in case of low plasma amino acid concentrations $(<1800$ $\mu \mathrm{mol} / \mathrm{L})$. Otherwise, cow's milk-based, special care formulas (Meb, Milupa, Friedrichsdorf, Germany; Humana O Frühnahrung, Humana Milchwerke e. G., Herford, Germany) were used (Table 1). All infants received 1000 IU of vitamin $D_{3}$ orally daily after the first week of life. Enteral feedings were started on the first day of life and complemented by parenteral nutrition during the first days.

Confirmative statistical analysis was limited to the evaluation
Table 1. Composition of formulas

\begin{tabular}{lccc}
\hline & $\begin{array}{c}\text { Humana } 0 \\
\text { Frühnahrung } \\
\text { per L }\end{array}$ & $\begin{array}{c}\text { Meb } \\
\text { per L }\end{array}$ & $\begin{array}{c}\text { Alfare per } \\
100 \mathrm{~g} \text { of } \\
\text { powder }\end{array}$ \\
\hline Ca (mmol) & 13 & 12.5 & 10 \\
Pi (mmol) & 12 & 13.3 & 1.29 \\
Protein (g) & 23 & 14 & 16.5 \\
Maltodextrin (g) & & & 44.9 \\
Starch (g) & & 87 & 6.0 \\
Lactose (g) & 86 & 38 & 0.8 \\
Fat (g) & 33 & & 24.0 \\
MCT (g)* & 3100 & 3160 & 2010 \\
Energy (kJ) & & & \\
\hline
\end{tabular}

* MCT, medium-chain triglycerides.

of the hypothesized differences in BMA between group 1 and group 2 (Mann-Whitney test).

\section{RESULTS}

The amount of supplemented $\mathrm{Ca}$ and/or $\mathrm{Pi}$ was gradually increased until a low urinary excretion of both $\mathrm{Ca}+\mathrm{Pi}$ was achieved. This goal was reached in only 30 of 74 studied periods (group 1). In this group, median bone mineral accretion was 5.1 $\mathrm{mg} \mathrm{cm}-1 / 100 \mathrm{~g}$ weight gain, which is equivalent to the intrauterine rate (4.5) (24). During the 44 periods, when simultaneous excretion of both $\mathrm{Ca}+\mathrm{Pi}$ was not observed in more than half of the urine samples (group 2), BMA was significantly lower (mean $2.4)$ than during periods when this goal was reached (group 1) (one-tailed probability; $p=0.012$ ) (Table 2 ).

BMA was proportional to the number of urine samples containing both $\mathrm{Ca}+\mathrm{Pi}$ (Fig. 1). The wide range of BMA in group 1 prompted us to look for factors that contribute to this variation. The BMC at the beginning of an observational period was significantly correlated with BMA during the next weeks; infants who had a BMC above the 50th percentile value for their body weight achieved only a low BMA or even lost bone mineral, whereas infants with low BMC yielded a more than average BMA (Fig. 2).

Further analysis revealed a coincidence of high BMA, a high percentage of $\mathrm{Ca}+\mathrm{Pi}$ positive urine samples and a low mineral status at the beginning of an observational period (Fig. 2).

\section{DISCUSSION}

The mineralization of skeletal tissue in vertebrate organisms is a complex and not completely understood process (27-30). The crystalline structure of apatite requires the presence of both $\mathrm{Ca}+\mathrm{Pi}$ in sufficient concentrations to form new crystallites. Conducive to the deposition of calcium phosphate minerals is an elevation of local $\mathrm{Ca}+\mathrm{Pi}$ concentration (25), but nothing is known about the plasma concentrations of either ion necessary to achieve the apatite accretion rate of the fetus in the preterm infant. In addition, what is a normal bone mineral accretion rate in VLBW infants? The only naturally provided yardstick for bone mineralization in preterm infants is the intrauterine bone mineral accretion rate during the same postmenstrual period. Intrauterine BMC is strongly and linearly related to body weight and, from cross-sectional data, the mineral accretion rate was calculated as $4.55 \mathrm{mg} \mathrm{cm}^{-1} / 100 \mathrm{~g}$ weight gain (24).

Greer and co-workers tried to achieve intrauterine mineralization rate in preterm infants by feeding a special-care formula highly enriched with $\mathrm{Ca}(1400 \mathrm{mg} / \mathrm{L})+\mathrm{Pi}(750 \mathrm{mg} / \mathrm{L})$ but then observed in some of their infants a zero rate or even a decrease in BMC (15). These varying results are probably explained by the considerable variation of the, on average, low Ca net absorption from cow's milk-based formulas in preterm infants $(31-40)$. The enteral supplementation, therefore, should be given individually to prevent demineralization in insufficiently supplemented 
Table 2. Bone mineral accretion rate in VLBW infants supplemented individually with $\mathrm{Ca}$ and/or $\mathrm{Pi}$, grouped according to urinary $\mathrm{Ca} / \mathrm{Pi}$ excretion

\begin{tabular}{|c|c|c|}
\hline & \multicolumn{2}{|c|}{$\begin{array}{c}\text { Type of urinary } \mathrm{Ca} \text { and } \mathrm{Pi} \\
\text { excretion }\end{array}$} \\
\hline & Group 1 & Group 2 \\
\hline \multicolumn{3}{|c|}{ BMA (mg cm $\mathrm{cm}^{-1} / 100 \mathrm{~g}$ weight gain) } \\
\hline Median & $5.1^{*}$ & $2.4^{*}$ \\
\hline Range & $-2.2-13.3$ & $-19.1-14.4$ \\
\hline Periods & 30 & 44 \\
\hline \multicolumn{3}{|c|}{ Interval between two BMC measurements (wk) } \\
\hline Median & 3.9 & 3.8 \\
\hline Range & $2.2-6.0$ & $2.3-6.0$ \\
\hline \multicolumn{3}{|c|}{ Birth weight (g) } \\
\hline Median & 885 & 1005 \\
\hline Range & $430-1520$ & $530-1580$ \\
\hline \multicolumn{3}{|c|}{ Gestational age (wk) } \\
\hline Median & 27.5 & 28.5 \\
\hline Range & $25-32$ & $24-33$ \\
\hline \multicolumn{3}{|c|}{ Postmenstrual age (wk) $\dagger$} \\
\hline Median & 51.6 & 50.4 \\
\hline Range & $46.5-63.2$ & $41.5-72.2$ \\
\hline \multicolumn{3}{|c|}{ Postnatal age (wk) $\dagger$} \\
\hline Median & 11.1 & 6.7 \\
\hline Range & $1.8-23.7$ & $2.0-24.2$ \\
\hline \multicolumn{3}{|c|}{ Body weight (g)† } \\
\hline Median & 2519 & 2295 \\
\hline Range & $1455-4620$ & $1293-4222$ \\
\hline \multicolumn{3}{|c|}{ Daily weight gain (g) $\dagger$} \\
\hline Median & 18.2 & 18.0 \\
\hline Range & $9.0-40$ & $7.5-30$ \\
\hline \multicolumn{3}{|c|}{$\mathrm{Ca} \neq\left(\mathrm{mmol} \mathrm{kg}{ }^{-1} \mathrm{~d}^{-1}\right)$} \\
\hline Median & 4.2 & 5.6 \\
\hline Range & $2.4-8.5$ & $2.0-9.0$ \\
\hline \multicolumn{3}{|c|}{ Pił $\left(\mathrm{mmol} \mathrm{kg}^{-1} \mathrm{~d}^{-1}\right)$} \\
\hline Median & 2.3 & 2.3 \\
\hline Range & $1.6-7.5$ & $1.6-7.5$ \\
\hline \multicolumn{3}{|c|}{ Bone $\mathrm{M}$ status $\S(\mathrm{mg} / \mathrm{cm})$} \\
\hline Median & -20 & -13 \\
\hline Range & $-56-15$ & $-48-71$ \\
\hline
\end{tabular}

* Significant difference between group 1 and group 2; one-tailed probability, $p=0.012$.

+ Mean value calculated for the interval between the first and second BMC measurement.

$\ddagger$ Total amount provided by milk and supplement.

$\S$ Bone mineral status $=\mathrm{BMC}$ at the beginning of an observational period minus the 50th percentile value in newborn infants of the same body weight at birth.

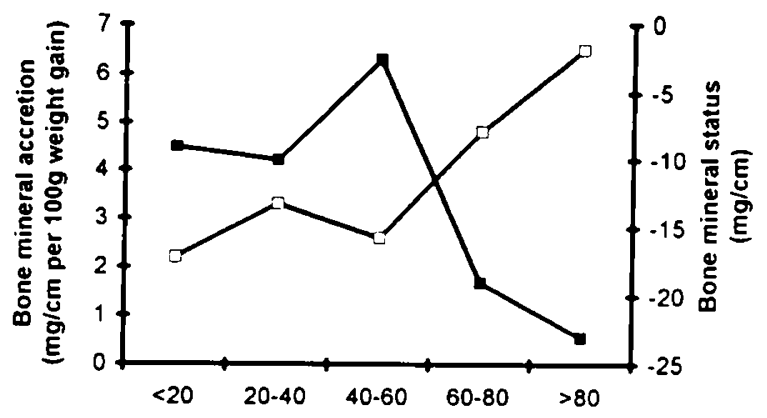

Percentage of urine samples containing $\mathrm{Ca}+\mathrm{Pi}$

Fig. 1. Correlation between the bone mineral accretion rate $(\square-\square)$ and the percentage of urine samples containing both $\mathrm{Ca}+\mathrm{Pi}$ and the bone mineral status ( $\square$ ) (BMC at the beginning of an observational period minus the 50th percentile BMC value at birth in newborn infants of the same body weight).

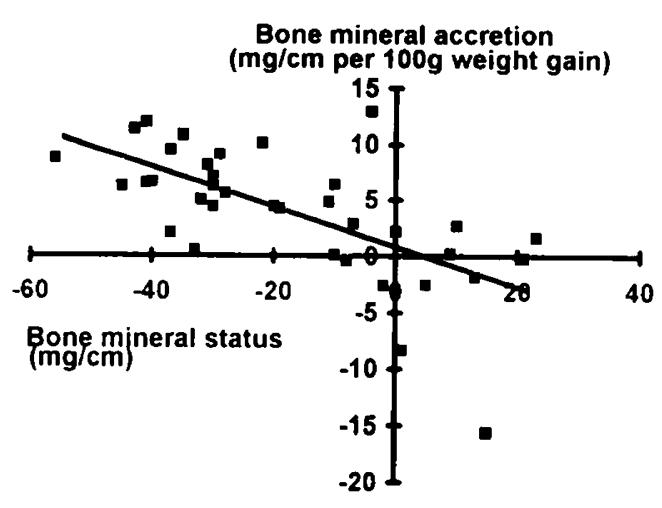

Fig. 2. Correlation between the bone mineral accretion rate and the bone mineral status (BMC at the beginning of an observational period minus the 50th percentile BMC value at birth in newborn infants of the same body weight) in preterm infants excreting $\mathrm{Ca}+\mathrm{Pi}$ in more than $50 \%$ of spot urine samples (group 1); $\mathrm{BMA}=-0.178 \mathrm{BM}$ status +0.83 , $r^{2}=0.42 ; p=0.00001$.

infants and also to avoid the potential risk of nephrocalcinosis through overdose. The individual measurement of enteral Ca net absorption is a time-consuming procedure, unsuitable for clinical routine. The easy-to-do measurement of $\mathrm{Ca}$ and $\mathrm{Pi}$ in urine spot specimens seemed to us to be a simple way of monitoring the supplementation. In VLBW infants fed every 2 to $3 \mathrm{~h}$, we found that measurements of $<1.2 \mathrm{mmol}$ of $\mathrm{Ca}$ and $<0.4 \mathrm{mmol}$ of $\mathrm{Pi}$, respectively (the lower limits of detectability with our method), n a spot urine specimen were representative for all spot urine specimens delivered over $24 \mathrm{~h}$. We also observed, $1 \mathrm{~d}$ thereafter, a urinary excretion of $\mathrm{Ca}$ and/or $\mathrm{Pi}$ as a rapid response to sufficient supplementation. We therefore took the absence of $\mathrm{Ca}$ and/or $\mathrm{Pi}$ from the urine as a sign of $\mathrm{Ca}$ and/or Pi deficiency, which we then enterally and/or parenterally compensated for until low urinary concentration showed a slight surplus.

The positive correlation between the percentage of $\mathrm{Ca}+\mathrm{Pi}$ positive urinary samples and the BMA rate and the significant difference in BMA between the infants who excreted $\mathrm{Ca}+\mathrm{Pi}$ together in more than $50 \%$ or fewer than $50 \%$ of the measured urine samples supported our hypothesis that the supplementation of preterm infants with $\mathrm{Ca}$ and $\mathrm{Pi}$ to yield postnatally an intrauterine BMA can be monitored by measuring the urinary concentrations of both ions.

A high BMA was also correlated with a low BMC at the beginning of an observational period (Fig. 2). A stepwise linear regression even revealed that the $\mathrm{BMC}$ at the beginning contributed more than the $\mathrm{Ca}+\mathrm{Pi}$ excretion to the variance of BMA. But this correlation makes sense only in connection with a simultaneous sufficient supplementation with minerals and the coincidence of high BMA rates, high $\mathrm{Ca}+\mathrm{Pi}$ excretion rates and a low starting BMC can be easily explained by the design of our study. The supplements were increased so slowly that the simultaneous excretion of $\mathrm{Ca}+\mathrm{Pi}$ was not achieved until a median postnatal age of $11 \mathrm{wk}$. During this long period the infants did not receive sufficient amounts of $\mathrm{Ca}+\mathrm{Pi}$ to achieve the intrauterine BMA. In some infants the bones were even demineralized in order to have some material for the mineralization of the newly grown parts of the skeleton. But eventually the supplement met requirements and then the infants with the lowest BMC yielded the higher BMA, i.e. a catch-up mineralization took place.

The net absorption of $\mathrm{Ca}$ from cow's milk-based formulas is low in preterm infants, varies considerably interindividually and reaches only $50 \%$ at $60 \mathrm{~d}$ postnatal age (36). Our findings are consistent with the concept of a maturation of $\mathrm{Ca}$ absorption. In group 1, the median dose of $\mathrm{Ca}$ required to yield a urinary excretion of Ca was $4.2 \mathrm{mmol} / \mathrm{kg} / \mathrm{d}$ and varied considerably between 2.4 and 8.5 . The median age was $11.1 \mathrm{wk}$. The infants in group 2 , however, were younger (6.7 wk) and their Ca absorp- 
tion must have been lower than in group 1, because even a higher dose of $\mathrm{Ca}$ (5.6) did not reach the target of a continuous urinary excretion of $\mathrm{Ca}$.

The gradual increase of supplementation was obviously too slow, because the simultaneous excretion of $\mathrm{Ca}+\mathrm{Pi}$ in more than half of the urine specimens (group 1) was only achieved in 30 of 74 studied periods and not until a median postnatal age of $11 \mathrm{wk}$. Average daily $\mathrm{Ca}(\mathrm{Pi})$ accretion was calculated from the content of fetal bodies at different gestational ages as $3.2(2.5)$ $\mathrm{mmol} / \mathrm{kg}(22,41-44)$. Assuming a rather good $50 \% \mathrm{Ca}$ net absorption, the enterally fed preterm infant should receive a total of $6.4 \mathrm{mmol}$ of $\mathrm{Ca} \mathrm{kg}^{-1} / \mathrm{d}$ in order to meet the requirement at the beginning of supplementation. The $\mathrm{Ca}$ supplement required depends on the Ca-concentration of the type of milk provided. It should bring the milk $\mathrm{Ca}$ content up to $6.4 \mathrm{mmol} / \mathrm{kg}$. In case of a continuing lack of urinary $\mathrm{Ca}$ excretion, the daily $\mathrm{Ca}$ dose should be increased each week by $2 \mathrm{mmol} \mathrm{kg}{ }^{-1}$. Phosphorus supplementation $(1-2 \mathrm{mmol} / \mathrm{kg})$ is mainly necessary in the breast milk-fed infant. Special-care formulas for preterm infants are sufficiently enriched with phosphorus.

The principle of $\mathrm{Pi}$ supplementation guided by urinary concentrations cannot be applied to infants with Pi-losing nephropathy. Here, Pi is excreted at low plasma Pi concentrations that do not allow normal mineralization (45). The same could be true for $\mathrm{Ca}$ in infants receiving a long-term treatment with furosemide that impairs the tubular reabsorption of $\mathrm{Ca}$.

The bone mineral accretion rate clearly correlated with the percentage of $\mathrm{Ca}+\mathrm{Pi}$-positive specimens and was highest in group 1. Confirming the wide variation of net $\mathrm{Ca}$ absorption we observed that a wide range of $\mathrm{Ca}$ was necessary to bring about slight urinary excretion (46). The daily doses of $\mathrm{Ca}+\mathrm{Pi}$ were added to the total daily milk volume in order to provide $\mathrm{Ca}+$ $\mathrm{Pi}$ simultaneously and constantly, around the clock. By doing this, the increase in osmolarity of the milk was kept as low as possible. No cases of intestinal obstruction or necrotizing enterocolitis were observed.

$\mathrm{Ca}$ added in large amounts to milk form insoluble $\mathrm{Ca}$ soaps and impair fat absorption, but a preliminary report showed the same weight in all infants independent of the amount of supplemented Ca (46).

Nephrocalcinosis and urolithiasis have been said to be a result of $\mathrm{Ca} / \mathrm{Pi}$ supplementation but are not likely to occur when the dose is monitored individually and increased gradually until urinary excretion starts in low concentrations. Twenty-four supplemented infants were examined longitudinally for nephrocalcinosis by ultrasound. Only one infant, who had received longterm treatment with furosemide, developed nephrocalcinosis (47).

We have presented evidence that our proposal offers a simple, effective and safe way of preventing bone demineralization in VLBW infants while taking into account individual needs and varying amounts of $\mathrm{Ca}$ and $\mathrm{Pi}$ in breast milk as well as formulas of differing compositions. However, although our study was prospectively designed and the gradually increased $\mathrm{Ca} / \mathrm{Pi}$ supplements were administered as planned, we retrospectively classified the infants as group 1 and group 2 . Therefore, a further prospective trial is needed to test our hypothesis.

\section{REFERENCES}

1. Ylppö A 1919 Zur Physiologie, Klinik und zum Schicksal der Frühgeborenen. Z Kinderheilkde 24:1-110

2. Hamilton B 1922 The calcium and phosphorus metabolism of prematurely born infants. Acta Paediatr 2:1-84

3. Muhl G 1926 The fat-absorption and the calcium metabolism of prematurely born infants: being a contribution to the knowledge of the pathpogenesis of rachitis in those infants. Acta Paediatr Scand 5:188-222

4. Von Sydow G 1946 A study of the development of rickets in premature infants. Acta Paediatr 33(suppl): $1-122$

5. Eek S, Gabrielsen LH, Halvorsen S 1957 Prematurity and rickets. Pediatrics 20:63-76

6. Willi H 1959 Zur Prophylaxe der Frühgeborenenrachitis. Helv Paediatr Acta $4: 351-371$
7. Gutcher GR, Chesney RW 1978 Iatronic rickets as a complication of a total parenteral nutrition program. The importance of providing calcium and vitamin D in the alimentation mixture. Clin Pediatr 17:817-819

8. Cifuentes RF, Kooh SW, Radde IC 1980 Vitamin D deficiency in a calciumsupplemented very low-birth-weight infant. J Pediatr 96:252-255

9. Kooh SW, Fraser D, Reilly BJ, Hamilton JR, Gall DG, Bell L 1977 Rickets due to calcium deficiency. N Engl J Med 297:1264-1266

10. Rowe JC, Wood DH, Rowe DW, Raisz LG 1979 Nutritional hypophosphatemic rickets in a premature infant fed breast milk. N Engl J Med 300:293296

11. Sagy M, Birenbaum E, Balin A, Orda S, Barzilay Z, Brish M 1980 Phosphatedepletion syndrome in a premature infant fed human milk. J Pediatr 96:683685

12. Koo W, Antony G, Stevens L 1982 Home treatment of hypophosphataemic rickets of prematurity by continuous phosphate infusion. Aust Paediatr $J$ 18:137(abstr)

13. Kovar IZ, Mayne PD, Robbe I 1983 Hypophosphataemic rickets in the preterm infant: hypocalcaemia after calcium and phosphorus supplementation. Arch Dis Child 58:629-631

14. Greer FR, Steichen JJ, Tsang RC 1982 Calcium and phosphate supplements in breast milk-related rickets. Am J Dis Child 136:581-583

15. Greer FR, Steichen JJ, Tsang RC 1982 Effects of increased calcium, phosphorus, and vitamin $D$ intake on bone mineralization in very low-birth-weight infants fed formulas with Polycose and medium-chain triglycerides. J Pediatr 100:951-955

16. Leape LL, Valaes T 1976 Rickets in low-birth-weight infants receiving tota parenteral nutrition. J Pediatr Surg 11:665-674

17. Binstadt DH, L'Heureux PR 1978 Rickets as a complication of intravenous hyperalimentation in infants. Pediatr Radiol 7:211-214

18. Kien CL, Browning C, Jona J, Starshak J 1982 Rickets in premature infants receiving parenteral nutrition: a case report and review of the literature. J Parenter Enteral Nutr 6:152-156

19. Gefter WB, Epstein DM, Anday EK, Dalinka MK 1982 Rickets presenting as multiple fractures in premature infants on hyperalimentation. Radiology 142:371-374

20. The TS, Kollee LAA, Boon JM, Monnens LAH 1983 Rickets in a preterm infant during intravenous alimentation. Acta Paediatr Scand 72:769-771

21. Schilling R, Haschke F, Kovarik J, Woloszczuk W 1982 Untersuchungen zum Phosphor- und Kalzium-Stoffwechsel Frühgeborener bei Ernährung mit Frauenmilch und mit einer adaptierten Milch. Pädiatr Pädol 17:667-674

22. Pohlandt F 1984 Bedarf an Kalzium, Phosphor, Magnesium und Vitamin D bei Frühgeborenen, Vermeidung von Knochenmineralmangel. In: Duc G (ed) Workshop für Neonatologen-Frühgeborene unter $1.500 \mathrm{~g}$ : Energiestoffwechsel am Krankenbett, Vieweg, Braunschweig, pp 127-147

23. Posner AS 1969 Crystal chemistry and bone mineral. Physiol Rev 49:760-792

24. Pohlandt $F$, Mathers $N 1989$ Bone mineral content of appropriate and light for gestational age preterm and term newborn infants. Acta Paediatr Scand 78:835-839

25. Ginder EM, King JD 1972 Rapid colorimetric determination of calcium in biological fluids. Am J Clin Pathol 58:376-382

26. Henry RJ 1974 Clinical Chemistry. Harper \& Row, New York.

27. Boskey AL 1981 Current concepts of the physiology and biochemistry of calcification. Clin Orthop Rel Res 157:225-257

28. Ali SY 1983 Calcification of cartilage. In: Hall BK (ed) Cartilage, Volume I, Structure, Function, and Biochemistry. Academic Press, New York, pp 343378

29. Eanes ED, Termine JD 1983 Calcium in mineralized tissues. In: Spiro TH (ed) Metal Ions in Biology, Volume 6, Calcium in Biology, John Wiley and Sons, New York, pp 203-233

30. Boskey AL, Posner AS 1984 Bone structure, composition, and mineralization. Orthop Clin North Am 15:597-612

31. Hövels O, Thilenius OG, Krafczyk S 1960 Untersuchungen zum Calciumund Phosphatstoffwechsel Frühgeborener. I. Der Einfluß des Angebotes, der Grundnahrung und des Calciumphosphorquotienten der Zufuhr auf die Calciumretention. Z Kinderheilkde 83:508-518

32. Paffrath H, Massart J 1933 Langfristige Untersuchungen des Mineral- und Wasserstoffwechsels bei Frühgeborenen. Z Kinderheilkde 54:343-366

33. Hoffman WS, Parmelee AH, Grossman A 1949 Electrolyte balance studies on premature infants on a diet of evaporated milk. Am J Dis Child 77:49-60

34. Sereni F, Pototschnig C, Sereni LP 1965 Latti vaccini a diverso contenuto proteico e salino: loro influenza su alcuni aspetti del metabolismo e dell'accrescimento dell'immaturo. Minerva Pediatr 17:1019-1024

35. Sutton A, Barltrop D 1973 Absorption, accretion and endogenous faecal excretion of calcium by the newborn infant. Nature 242:265-266

36. Day GM, Chance GW, Radde IC, Reilly BJ, Park E, Sheepers J 1975 Growth and mineral metabolism in very low birth-weight infants. II. Effects of calcium supplementation on growth and divalent cations. Pediatr Res 9:568575

37. Shaw, JCL 1976 Evidence for defective skeletal mineralization in low birthweight infants: the absorption of calcium and fat. Pediatrics 57:16-25

38. Senterre J, Lambrechts A 1972 Nitrogen, fat and minerals' balance in premature infants fed acidified or nonacidified half-skimmed cow milk. Biol Neonate 20:107-119

39. Shenai JP, Reynolds JW, Babson SG 1980 Nutritional balance studies in very low birth-weight infants. Enhanced nutrient retention rates by an experimental formula. Pediatrics 66:233-238

40. Senterre J, Salle B 1982 Calcium and phosphorus economy of the preterm 
infant and its interaction with vitamin D and its metabolites. Acta Paediatr Scand S296(suppl):85-92

41. Kelly HF, Sloan RE, Hoffman W, Saunders C 1951 Accumulation of nitrogen and six minerals in the human fetus during gestation. Hum Biol 23:61-74

42. Widdowson EM, Spray CM 1951 Chemical development in utero. Arch Dis Child 26:205-213

43. Widdowson EM, Dickerson JWT 196! II. The composition of the body as a whole. In: Comar CL, Bronner F (eds) Mineral Metabolism, Vol. II, Pt. A Academic Press, New York.
44. Fee BA, Weil WB 1963 Body composition of infants of diabetic mothers by direct analysis. Ann NY Acad Sci 110:869-897

45. Pohlandt F, Gortner L, Bartmann P 1988 Severe bone demineralization in preterm infants due to decreased tubular phosphate reabsorption (DTPR). Pediatr Res 24:275(abstr)

46. Pohlandt F, Gortner L, Bartmann P 1990 Weight gain of Ca-supplemented VLBW infants. Pediatr Res 27:289(abstr)

47. Pohlandt F, Müller M 1987 Renal echogenicity in VLBW infants supplemented with $\mathrm{Ca}$ and $\mathbf{P}$ to prevent bone demineralization. Pediatr Res 22:333(abstr)

\section{Announcement}

\section{International Congress of Pediatric Dermatology}

The VII International Congress of Pediatric Dermatology will be held in Buenos Aires, Argentina, from September 26th to October 1st, 1994. The main themes will be Atopic Dermatitis, Nutritional Disorders, AIDS, and Genodermatoses. For further information, please contact Dr. Adrián M. Pierini, President, VII International Congress of Pediatric Dermatology, Arenales 1446 Ap. 1 B, (1061) Buenos Aires, Argentina, phone (54.1) 8144068, fax (54.1) 812-9255. 